\section{Study Of Methods For Identification And Storage Of Morphological Features Of Grapes Grown In The Conditions Of Fergana Region}

\author{
Azizov Aktam Sharipovich, \\ Candidate Of Technical Sciences, Associate Professor, \\ Tashkent State Agrarian University, Uzbekistan \\ Yusupov Nurali Sheralievich, \\ Assistant, Andijan Branch Of Tashkent State Agrarian \\ University, Uzbekistan \\ Solieva Madina Botirovna, \\ Senior Lecturer, Andijan Branch Of Tashkent State \\ Agrarian University, Uzbekistan \\ Ermakova Jamilakhon Mukhammadovna, \\ Assistant, Andijan Branch Of Tashkent State Agrarian \\ University, Uzbekistan
}

\section{Gopen ACCESS}

The American Journal of Agriculture and Biomedical Engineering JULY 2020

Page No.: 20-24

Volume-II Issue-VII

PUBLISHED: 30 JULY 2020

www.usajournalshub.com/inde x.php/tajabe

Copyright: Original content from this work may be used under the terms of the Creative Commons Attribution 4.0 licence.

\title{
Abstract
}

The article provides information on the morphological features of grape varieties grown in Oltiariq district of Fergana region, methods of cultivation and the results of the study of their impact on the preservation of grapes.

Keywords: grape, variety, storage methods, technology, selection, agro-technical, export-oriented, register, food.

\section{Introduction}

Complex measures aimed at growing, storing, processing and exporting fruits, vegetables and grapes are being implemented in the country.

The application of advanced technologies of crop production in the sustainable development of fruit and vegetable growing, the introduction of modern methods of 
storage and processing of products will help to prevent today's food shortages. Not only to prevent the extinction of fruits and vegetables and grapes, but also to expand the area under crops and increase the gross yield, which imposes great challenges on specialists in this field [3, 2019].

\section{The Main Findings And Results}

In recent years, consistent measures have been taken to reform agriculture and introduce market mechanisms in the sector.

In particular, a cluster approach to agricultural production has been established, the volume of agricultural land allocated to the clusters is $67 \%$ in cotton and textiles, $8 \%$ in animal husbandry and $7.5 \%$ in fruit and vegetable growing.

As a result of processing of raw materials grown in the cluster method, it is possible to deliver to the consumer in the form of a finished product.

Today, more than 80 types of agricultural products grown in our country are exported to 66 countries around the world.

In the implication of this, first of all, great attention should be paid to the selection of cultivars and agro-technical processing processes. As fruits and vegetables ripen, it is better to harvest them on time and deliver them to the next stage in time $[1,2019]$. President of the Republic PD 4549 11.12. 2019 a press conference was held on "Analysis of the work being done to expand the scope of research in the field of horticulture, viticulture and winemaking, the creation of new export-oriented varieties, the reproduction of their varieties". It was noted that currently there are 82,540 hectares of vineyards at the disposal of agricultural enterprises, of which 37,785 hectares are cultivated with fodder, 30,640 hectares with raisins and 14,116 hectares with wine. About 66,000 hectares of existing vineyards have been harvested, and drip irrigation technology has been introduced on 2,600 hectares of vineyards. There are 45 grape varieties recommended for planting in the State Register of Agricultural Crops. One of the fruits and vegetables is grapes, which are loved and consumed not only in Uzbekistan but all over the world. 77.5 million tons of grapes are grown worldwide, of which $7 \%$ are raisins, $36 \%$ are food and $57 \%$ are wine $[2,2019 ; 3,2019 ; 4,2013]$. Therefore, one of the main ways to deliver edible grape varieties to consumers is to ensure that the high quality of the grape varieties, if they are freshly cut, is achieved through the process of storing them. Therefore, further improvement of research work on the preservation of grapes is an urgent issue $[8,2018]$.

Therefore, further improvement of research work on the preservation of grapes is an urgent issue.

Among these varieties, such varieties as Kara Janjal, Andijan black grapes, Buaki nor, Buaki stone, Bishti, Black and White raisins, Parkent, created from the grape food varieties, have not lost their place. [5, 1984]

\section{Methodology}

Grapes grown in our fields are rich in valuable nutrients for the human body: sugar, acids, and vitamins, biologically active and mineral substances. Therefore, it is important not only to increase the cultivation of grapes, but also to provide the population with grapes throughout the year. Proper storage of grapes will provide additional benefits and provide the population with barley grapes throughout the year. In this regard, Tashkent State 
ISSN (e): 2689-1018

DOI: https://doi.org/10.37547/tajabe/Volume02Issue07-03

Agrarian University and its affiliates, professors, masters and bachelors, as well as the United States Agency for International Development (USAID) in the framework of the project "Study of technological parameters of storage of grape varieties grown in different climatic conditions of the country"; experiments were conducted in collaboration with grape growers. The purpose of the experiment is to theoretically scientifically substantiate the practice of storing grapes in modern refrigerated warehouses. In the framework of this project, we conducted research on the process of storage of grapes grown in the Fergana region in refrigerated warehouses [7, 2020].

In the storage of grapes in refrigerated warehouses is important to study the morphological signs of decay, mainly due to the natural decrease in relative humidity air temperature (Fig. 1).

\section{The results of the research and their discussion}

As a result of long-term storage of Husain, Mers, Kelinbarmok white, Kelinbarmok black varieties of grapes grown in Fergana region as a result of our research, eight-year-old vines are grown in Khairullo Bakhrom farm of Oltiariq district of Fergana region the color of the following grape varieties, the weight of one head of grapes, the weight of ten grapes, the thickness of the peel of the grape, the diameter of the grape, were studied before placing the cultivated grapes in refrigerated warehouses. The morphological features of the grapes were studied during the study. The refrigeration is shown in the processes carried out before storage (Table 1 ).

\section{Table-1}

Morphological features of different food varieties of grapes

\begin{tabular}{|c|c|c|c|c|c|c|}
\hline № & Sort & Color & $\begin{array}{l}\text { Weight of } \\
\text { one head } \\
\text { of grapes, } \\
\text { gr. }\end{array}$ & $\begin{array}{l}\text { Weight of } \\
10 \text { grains, } \\
\text { gr. }\end{array}$ & $\begin{array}{l}\text { Hardness } \\
\text { Level, gr / } \\
\text { mm2. }\end{array}$ & $\begin{array}{l}\text { Grapes } \\
\text { diameter, } \\
\mathrm{mm} \text {. }\end{array}$ \\
\hline 1 & Hussein & White & 940 & 78 & 250 & 230 \\
\hline 2 & Mers & Red & 495 & 96 & 295 & 301 \\
\hline 3 & Kelinbarmok & White & 820 & 68 & 250 & 108 \\
\hline 4 & Kelinbarmok & Black & 730 & 83 & 180 & 210 \\
\hline
\end{tabular}

Results of 90-day storage of edible grape varieties in the Refrigerated Warehouse in Oltiariq district of Fergana region.

Shown in Table 2.

Table 2 


\begin{tabular}{|l|l|l|l|l|l|l|}
\hline № & Sort & Color & $\begin{array}{l}\text { Weight of } \\
\text { one head } \\
\text { of grapes, } \\
\text { gr. }\end{array}$ & $\begin{array}{l}\text { Weight of } \\
10 \text { grains, } \\
\text { gr. }\end{array}$ & $\begin{array}{l}\text { Hardness } \\
\text { Level, gr / } \\
\text { mm2. }\end{array}$ & $\begin{array}{l}\text { Grapes } \\
\text { diameter, } \\
\text { mm. }\end{array}$ \\
\cline { 2 - 7 } & Hussein & White & 776 & 74 & 300 & 210 \\
\hline 2 & Mers & Red & 463 & 95,5 & 320 & 300 \\
\hline 3 & Kelinbarmok & White & 615 & 67,5 & 200 & 195,4 \\
\hline 4 & Kelinbarmok & Black & 615 & 81 & 200 & 205 \\
\hline
\end{tabular}

Storage of grape products during storage in refrigerated warehouses, the storage temperature was $2{ }^{\circ} \mathrm{C}$; relative humidity was $70-80 \%$, with a small natural decrease and maintaining the quality indicators.

As a result of the research, it was found that the white variety of Hussein weighed $940 \mathrm{~g}$ per head of grapes before storage in the refrigerator during storage, and $776 \mathrm{~g}$ in post-storage condition; 10 pieces weighing $78 \mathrm{~g}$ before being placed in a refrigerated warehouse; condition after storage 10 grains weighing $74 \mathrm{~g}$; hardness level before storage $250 \mathrm{gr} / \mathrm{mm} 2$, post-storage hardness level $300 \mathrm{gr} / \mathrm{mm} 2$; pre-storage diameter $230 \mathrm{~mm}$ post-storage $210 \mathrm{~mm}$.

Mers variety weighs $495 \mathrm{~g}$ before storage and 10 grapes after storage weighs $96.5 \mathrm{~g}$ before storage and $463 \mathrm{~g}$ before storage. hardness level before storage $295 \mathrm{gr} / \mathrm{mm} 2$, post-storage hardness level $320 \mathrm{gr} / \mathrm{mm} 2$; pre-storage diameter $301 \mathrm{~mm}$ post-storage $300 \mathrm{~mm}$.

Before putting the brisket variety in storage, if it is $820 \mathrm{~g}$, in the condition after storage; $615 \mathrm{gr} 10$ pieces weighing $68 \mathrm{gr}$; weight of 10 grape grains after storage $67.5 \mathrm{~g}$; hardness level before storage $250 \mathrm{gr} / \mathrm{mm} 2$, post-storage hardness level $200 \mathrm{gr} / \mathrm{mm} 2$; pre-storage diameter $108 \mathrm{~mm}$ post-storage $107 \mathrm{~mm}$.

The bridal variety is $730 \mathrm{~g}$ before storage and $615 \mathrm{~g}$ after storage; 10 grains weighing $83 \mathrm{~g} 10$ grains weighing $81 \mathrm{~g}$ after storage; hardness level before storage $210 \mathrm{~g}$ / mm2; post-storage hardness level $200 \mathrm{gr} / \mathrm{mm} 2$; diameter before storage $210 \mathrm{~mm}$; we found from our experiments that it was $205 \mathrm{~mm}$ after storage. The measurement method is given in Figure 1 (Figure 1). 


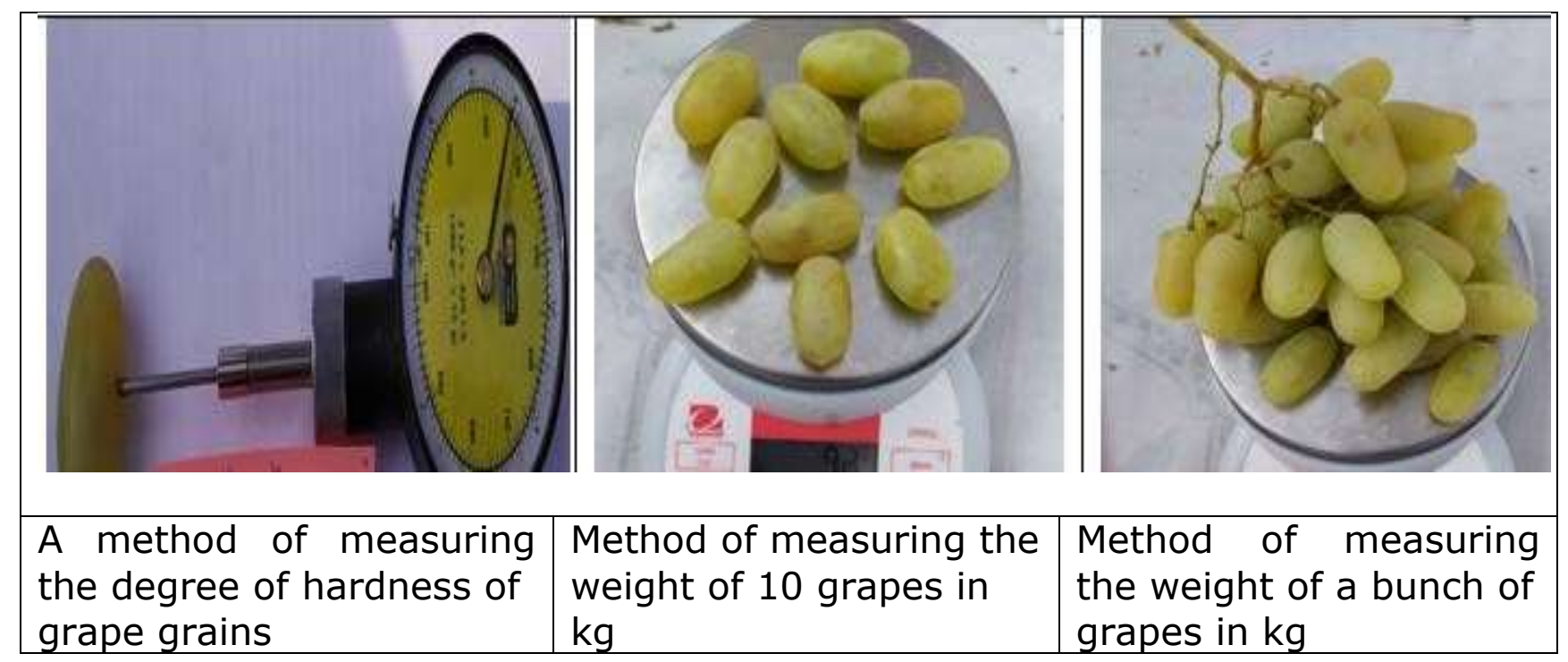

\section{Conclusion}

During the storage process, the natural decrease of grape mers and black currant varieties was less than that of husain and white currant varieties. It was found that the natural decrease of colored grape varieties was less than that of colorless grapes.

\section{References}

[1]. PD 4549 of the President of the Republic of Uzbekistan 11.12. 2019

[2]. Resolution of the President of the Republic of Uzbekistan dated March 14, 2019 No PP-4239 "On measures to develop agricultural cooperation in the field of fruit and vegetables."

[3]. Decree of the President of the Republic of Uzbekistan dated March 14, 2019.

[4]. R.M.Abdullaev and others. (2013) GRAPE GROWING AND RAISINE PRODUCTION «SHARQ» NASH RIYOT-M ATBAA JOINT STOCK COMPANY. - Tashkent.

[5]. Mirzaev M.M et al. (1984) Ampelography of Uzbekistan. - Tashkent. Uzbekistan.

[6]. Oripov R, Sulaymonov I, Umurzoqov E. (1991) "Technology of storage and processing of agricultural products". - Tashkent. Mehnat.

[7]. Scientific-practical seminar on "The role of refrigerators in the storage of fruits and vegetables, the current state and prospects of the industry" held in the framework of the AVC project "Development of the value chain in agriculture" of the USID International Agency Tashkent. 2020.

[8]. Azizov A.Sh. (2018) Technologies for storage and processing of fruits and vegetables on the basis of innovative technologies TashDAU editorial publishing house. - Tashkent. p. 64

\section{Internet Sources}

[1]. Source: https://rusfermer.net/forlady/hranenie/grushi Russian farmer (c) Portal for the owners of their land: farmers, summer residents and gardeners!

[2]. https://www.lex.uz/docs/4641169

[3]. uza.uz/oz/society/tokzorlar-24-09-2019 